\title{
PHYSICAL ACTIVITY OF TRUCK DRIVERS
}

\author{
Jana JURIKOVA ${ }^{1 *}$, Sandra BERGEROVA ${ }^{1}$ \\ ${ }^{1}$ Masaryk University, Faculty of Sports Studies, Brno, Czech Republic \\ *Corresponding author: jurikova@fsps.muni.cz
}

DOI: $10.35189 /$ iphm.icpesk.2019.17

\begin{abstract}
The profession of a truck driver is very demanding both mentally and physically. It requires a high level of psychological resistance during the work under pressure from their superiors and dispatchers, typically in time constraints. The aim of this study was to analyse movement habits of truck drivers. These habits are in direct dependence on conditions and circumstances of the work performance. Within a questionnaire survey, we built up a questionnaire which was further spread electronically. The survey was attended by 270 people - mostly men (96.3\%), whose average age was 38.7 and who were doing this job for 20-30 years (46\% of respondents). Most drivers put on weight during this job (68\% of respondents), specifically, the gain was between 10 and $20 \mathrm{~kg}$ (38\% of respondents). The frequency of their meals is between 3 and 4 times a day (43\% of respondents), or even 1-2 times a day (44\% of respondents). 59\% of respondents report that they do not have a regular sleeping regimen. Concerning their physical activity, 39\% of respondents perform physical activity more than 5 times a week, mostly in their leisure time (54\% of respondents). The most popular activities of truck drivers are run, rope skipping, pressups, squats, sit-ups and weight lifting.
\end{abstract}

Keywords: truck drivers, health, sleep, physical activity, exercise.

\section{Introduction}

Driving is a complex and dynamic activity requiring several cognitive processes to perform safely. The cognitive processes associated with driving include executive functions, specifically, the ability to inhibit distractions, update information and shift attention from one task to another (Anstey, Wood, Lord, \& Walker, 2005; Fisher, Rizzo, Caird, \& Lee, 2011; Trick, Enns, Mills, \& Vavrik, 2004; Miller, Taylor-Piliae, \& Insel, 2016).

Being a truck driver is, both mentally and physically, a demanding job. It requires extreme resistance to working under pressure, is demanding in terms of road safety and it is also necessary to face high pressure from managers and dispatchers. A driver must often deal with a language barrier or navigation system failure, plus loading and unloading several tons of goods. The character of this profession suggests that, if the person is not well trained, loading goods might represent an unpleasant burden. A driver must work with a wide range of goods and is endangered by occupational injury risks not only on the road. He has to follow numerous traffic rules and have a good command of legislation of various countries.

Drivers typically spend their working hours on their seats, often without contact with family or friends for several weeks, and spend their leisure time in car parks, pull-in or petrol station areas. Due to personal safety reasons, it is not advisable to spend long time in these places, so drivers stay locked inside the cab. These areas provide facilities of different quality and hygiene standards, such as toilets and showers, opportunities for sport activity, shopping for food and personal goods, as well as preparing their meals. Sometimes, food supplies are limited to their own sources or shopping at petrol stations, which means higher financial costs. Food preparation is complicated by a limited space and difficulties with kitchen, water and electricity availability. All factors mentioned above necessarily reflect the quality of one's diet, which is a fundamental attribute to ensure proper function of the human body and mental well-being.

The mental stress of work further influences the physical body and health. Medical problems are escalated by the poor quality of food, irregular eating regimen and insufficient sleep, lack of physical activity and long hours spent sitting. Drivers face an increased risk of numerous diseases. Medical, psychological and professional capability to drive a vehicle is defined by Act no. 361/2000 Coll. on Road Traffic ("Zákon č. 361/2000 Sb. o Provozu na Pozemních Komunikacích", 2000).

The driving licence for truck drivers is $\mathrm{C}$ or $\mathrm{C}+\mathrm{E}$ category and can be obtained after the age of 21 years. An applicant has to undergo the initial medical examination, and then regular examination every second year, and after 50 years of age, the frequency of examination is once a year. Prior to work performance itself, it is necessary to pass traffic psychological examination, which is necessary to be repeated at the age of 50, and then every 5 years (Poláček, 2017). These tests are obligatory for all second-class drivers - vehicles above 7.5 tons - in order to obtain their professional driving licence (Šucha, Černochová, Rehnová, Šrámková, \& Zámečník, 2015). 
Working hours arrangements and alteration between work and relax are subject to international legislation. This concerns daily time spent driving, daily rest, maximal week and fortnight limits for driving, weekly relax and maximal continuous driving time (Jurnikl, 1986). These provisions are defined by the AETR (European Agreement Concerning the Work of Crews of Vehicles Engaged in International Road Transport) (Poláček, 2017).

Daily time for driving cannot exceed 9 hours and can be prolonged up to 10 hours twice a week. Total driving time can be up to 56 hours weekly and total driving time in two successive weeks is maximum 90 hours. Driving time has to be interspersed with safety breaks - a 45 -minute break follows four-and-half-hour drive. This time can be divided into intervals of 15 or 30 minutes. Break time cannot be interchanged with time for rest. Waiting time and time spent inside the vehicle but not devoted to driving (i.e. on ferry-boat or train) is not considered as different work and therefore cannot be considered as a safety break.

A driver can digress from the AETR Agreement as long as it is necessary to reach a convenient rest place to ensure the safety of people, vehicle and cargo unless he poses a threat to road safety (Poláček, 2017).

\section{Purpose}

The aim of this study is to define anthropometric parameters (body weight, height, body mass index) of truck drivers and find out whether drivers manage to perform physical activities under the conditions given by the character of their profession.

\section{Material and Methods}

The survey was carried out using the questionnaire method. The questionnaire consisted of 19 questions. The first part focused on general information about the age, gender, body weight and height of respondents. The next questions aimed at their eating habits, drinking regimen, sleeping regimen, disease incidence and physical activity. Questionnaires were distributed via e-mail and Facebook social network. Participants responded anonymously via the Click4Survey Internet application. 476 people opened the survey, but only $270(56.7 \%)$ returned the completed questionnaire.

Among the 270 respondents who participated in the survey, 10 (3.7\%) were women. Because of the negligible representation of women in the group of respondents, the sample was not divided by gender but was considered as a whole. The age of respondents is shown in Table 1.

Table 1. Age of respondents

\begin{tabular}{cccccccc}
\hline Age & $\begin{array}{c}\text { Response } \\
\text { frequency }\end{array}$ & Age & $\begin{array}{c}\text { Response } \\
\text { frequency }\end{array}$ & Age & $\begin{array}{c}\text { Response } \\
\text { frequency }\end{array}$ & Age & $\begin{array}{c}\text { Response } \\
\text { frequency }\end{array}$ \\
\hline 18 & 1 & 32 & 7 & 45 & 16 & 58 & 0 \\
19 & 0 & 33 & 11 & 46 & 14 & 59 & 1 \\
20 & 2 & 34 & 10 & 47 & 7 & 60 & 1 \\
21 & 4 & 35 & 2 & 48 & 8 & 61 & 0 \\
22 & 4 & 36 & 9 & 49 & 7 & 62 & 1 \\
23 & 5 & 37 & 6 & 50 & 5 & 63 & 1 \\
24 & 3 & 38 & 8 & 51 & 5 & 64 & 1 \\
25 & 6 & 39 & 8 & 52 & 3 & 65 & 0 \\
26 & 3 & 40 & 10 & 53 & 4 & 66 & 0 \\
27 & 10 & 41 & 7 & 54 & 4 & 67 & 0 \\
28 & 8 & 42 & 16 & 55 & 6 & 68 & 0 \\
29 & 11 & 43 & 11 & 56 & 0 & 69 & 0 \\
30 & 12 & 44 & 5 & 57 & 2 & 70 & 1 \\
\hline 31 & 5 & & & & & &
\end{tabular}

$\begin{array}{ll}31 & 5 \\ \text { Source: Study of authors }\end{array}$

The surveyed respondents were aged 18-70, the average age being $38.7( \pm 9.95)$. After the age of 50, we can observe a decreasing number of active drivers. This situation reflects the fact that drivers, after their 50th birthday, have to undergo medical examination annually and also have to repeat traffic-psychological examination. Three respondents were younger than 21 , which is the age limit for obtaining a driving licence for truck vehicles. This 
licence can be obtained by fulfilling the special conditions after the age of 18 years. The table above shows that most active drivers are aged between 42 and 46 years.

Respondents were asked to provide their body weight and height. Relying on these data, their body mass index (BMI) was calculated, and respondents were divided into categories according to BMI (Table 2).

$$
\mathrm{BMI}=\frac{\text { body weight }[\mathrm{kg}]}{\{\text { body height }[\mathrm{m}]\}^{2}}
$$

Table 2. The international classification of adult underweight, overweight and obesity according to BMI

\begin{tabular}{lcc}
\hline \multicolumn{1}{c}{ Classification } & \multicolumn{2}{c}{ BMI $\left(\mathrm{kg} / \mathrm{m}^{2}\right)$} \\
\cline { 2 - 3 } & Principal cut-off points & Additional cut-off points \\
\hline Underweight & $<18.50$ & $<18.50$ \\
Severe thinness & $<16.00$ & $<16.00$ \\
Moderate thinness & $16.00-16.99$ & $16.00-16.99$ \\
Mild thinness & $17.00-18.49$ & $17.00-18.49$ \\
Normal range & $18.50-24.99$ & $18.50-22.99$ \\
Overweight & $\geq 25.00$ & $23.00-24.99$ \\
Pre-obese & $25.00-29.99$ & $\geq 25.00$ \\
Obese & $\geq 30.00$ & $25.00-27.49$ \\
Obe e class I & $30.00-34.99$ & $\geq 30.00$ \\
& & $30.00-32.49$ \\
Obese class II & $35.00-39.99$ & $32.50-34.99$ \\
Obese class III & $\geq 40.00$ & $37.50-39.99$ \\
\hline
\end{tabular}

Source: Adapted from WHO (1995, 2000 and 2004)

\section{Results and Discussion}

On the basis of body weight and height, the BMI of respondents was calculated and they were divided into categories accordingly (Figure 1).

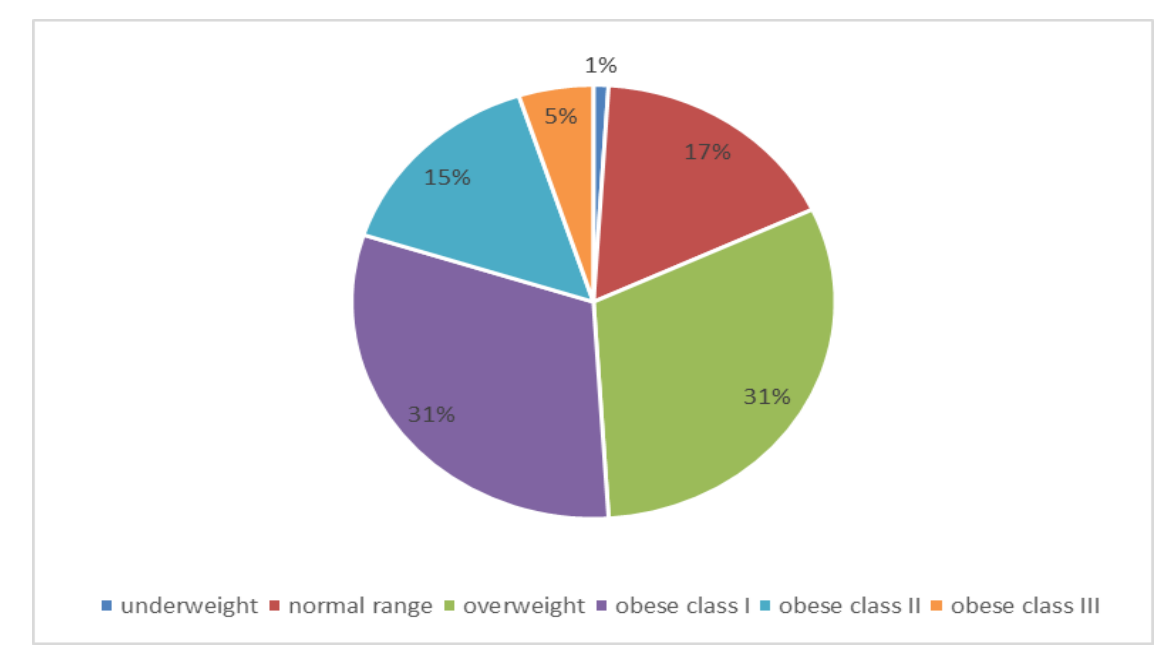

Figure 1. BMI of respondents (Source: Study of authors) 
The largest group consists of drivers with overweight and first-degree obesity $-31 \%$ of respondents for each case. Very high risks are related to third-degree obesity, which was diagnosed in 5\% of respondents. Merely $17 \%$ have normal body weight, and $82 \%$ are above the normal-weight limit (overweight or obesity). First-, second- and third-degree obesity was found in $51 \%$ of respondents, which corresponds to the findings of foreign authors. Several studies measured the prevalence of obesity in commercial drivers, and all of them found that more than $50 \%$ of their samples included obese people (Albert et al., 2014; Angeles et al., 2014; Apostolopoulos, Sönmez, Shatell, Gonzales, \& Fehrenbacher, 2013; Hege, Apostolopoulos, Perko, Sönmez, \& Strack, 2016; Lemke, Hege, Perko, Sönmez, \& Apostolopoulos, 2015; Ronna et al., 2016; Sieber et al., 2014; Thiese et al., 2015a; Thiese et al., 2015b; Crizzle et al., 2017).

The next question asked respondents to say how long they were being employed as professional truck drivers. Their responses are shown in Figure 2.

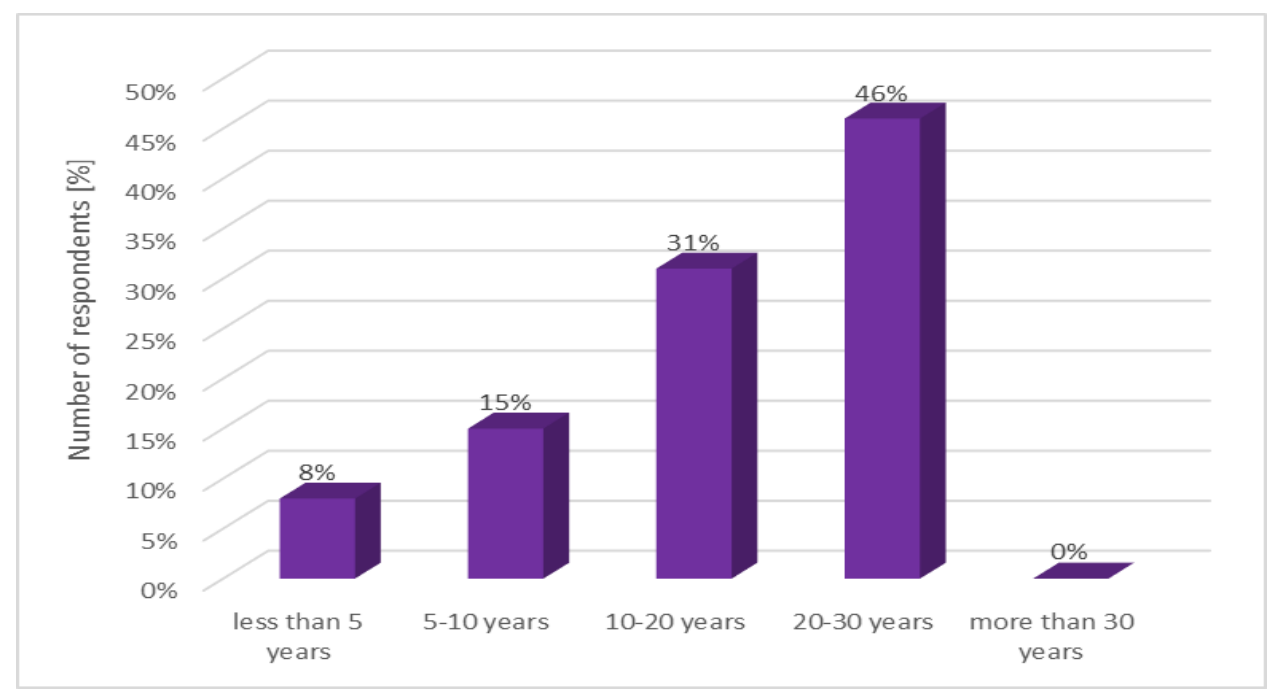

Figure 2. Length of job performance (Source: Study of authors)

As seen in the figure above, nearly half of respondents (46\%) perform this job for 20-30 years. The shortest time interval (less than 5 years) was chosen by the fewest respondents $(8 \%)$.

The next question examined the self-esteem of respondents. They were asked whether the job of a professional driver had an influence on their body weight and, if so, whether their weight has increased or decreased. Their responses are shown in Figure 3.

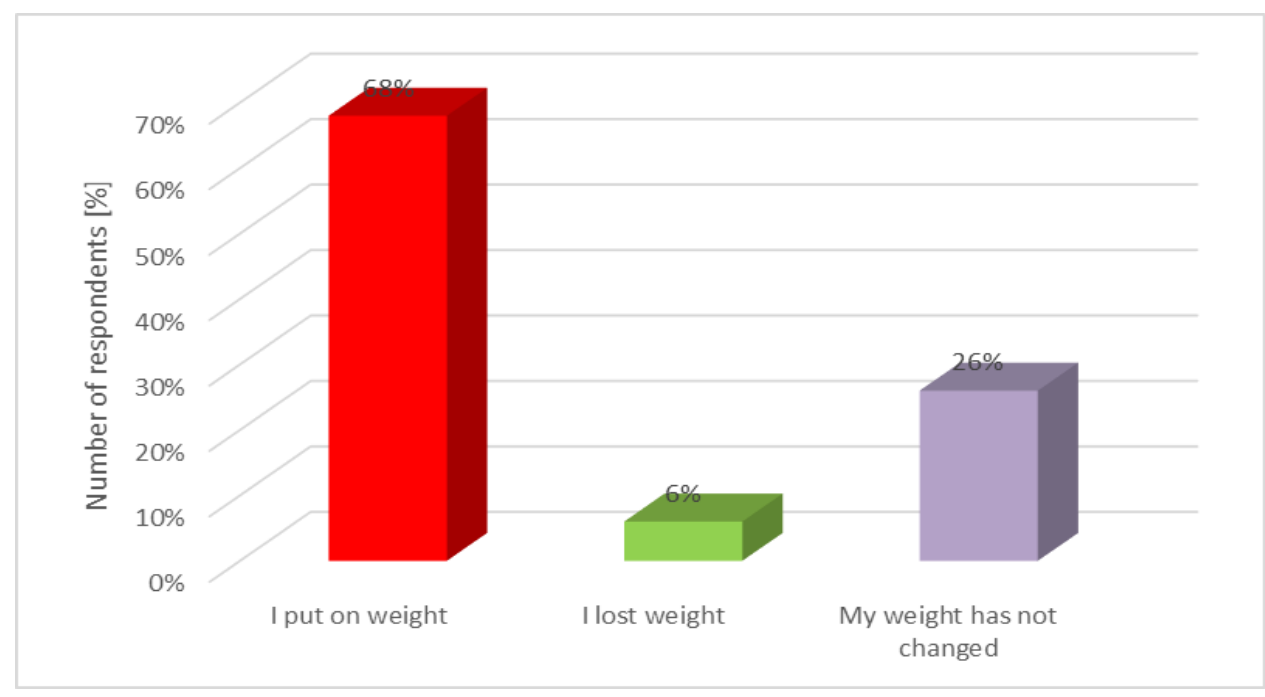

Figure 3. Changes in body weight in relation to a truck driver job (Source: Study of authors) 
The figure above shows that body weight has changed in $74 \%$ of respondents during their job performance; of them, $68 \%$ have put on weight, and $6 \%$ have lost weight. It can be said that the profession of a truck driver represents a sedentary job with a risk of weight increase. Recent studies have found that long-haul truck drivers are highly susceptible to cardiovascular disease, type 2 diabetes and obesity (Sangaleti et al., 2014; Sieber, 2014; Puhkala et al., 2015; Rosso, Perotto, Feola, Bruno, \& Caramella, 2015; Gilson et al., 2017). This mainly occurs because of long hours spent sitting and tight delivery deadlines; on the other hand, unsupportive physical environment and work culture restrict the time and opportunity for drivers to effectively manage energy balance through regular physical activity and healthy dietary options (Gilson et al., 2017).

The risk of obesity incidence is also related to their irregular eating regimen. Another question focused on the number of meals that drivers eat per day. The processed results are shown in Figure 4.

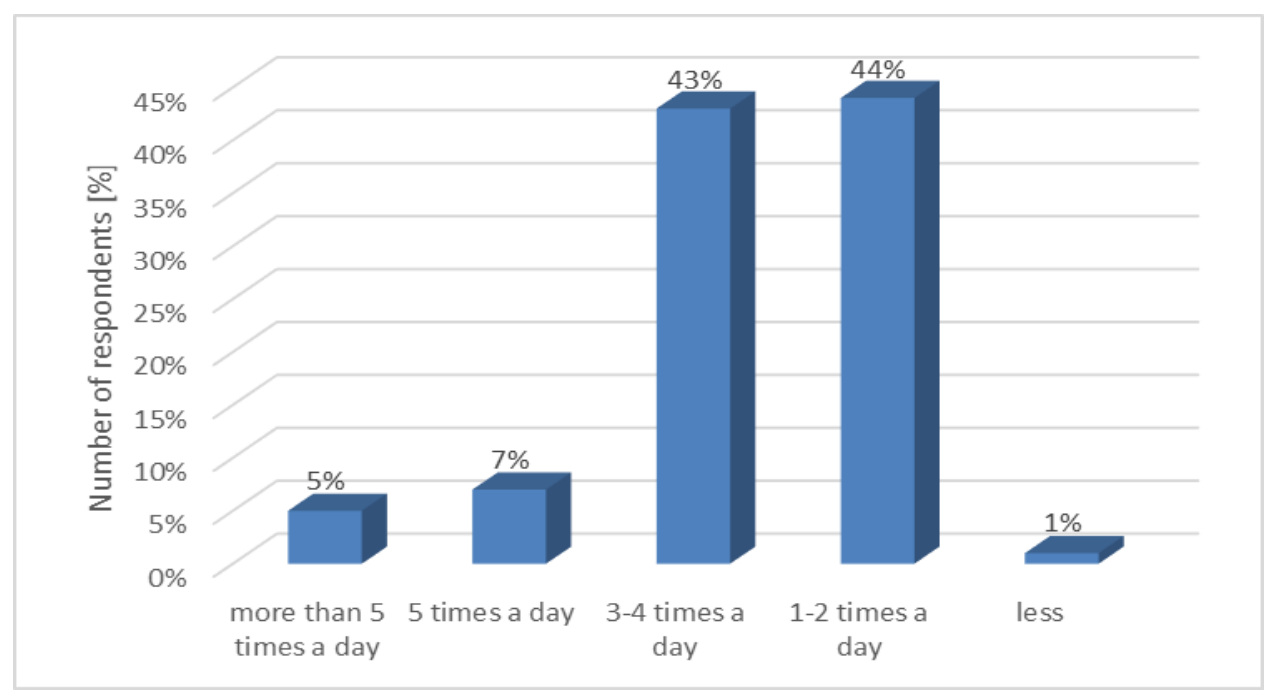

Figure 4. Daily frequency of eating (Source: Study of authors)

The responses have revealed that $44 \%$ of drivers eat only $1-2$ times a day, and $43 \%$ have $3-4$ meals a day. However, healthy eating habits recommend that a person should have 5 or more meals a day, which is respected by $12 \%$ of drivers.

Sleep duration and quality are very important. Long driving hours, shift work and time pressure have been recognised as key factors impacting sleep deficit, fatigue and road accidents in truck drivers (Marqueze, Ulhoa, \& Moreno, 2012; Gilson et al., 2017). Therefore, the next question attempted to find out how many hours truck drivers used to sleep daily. Their responses are shown in Figure 5.

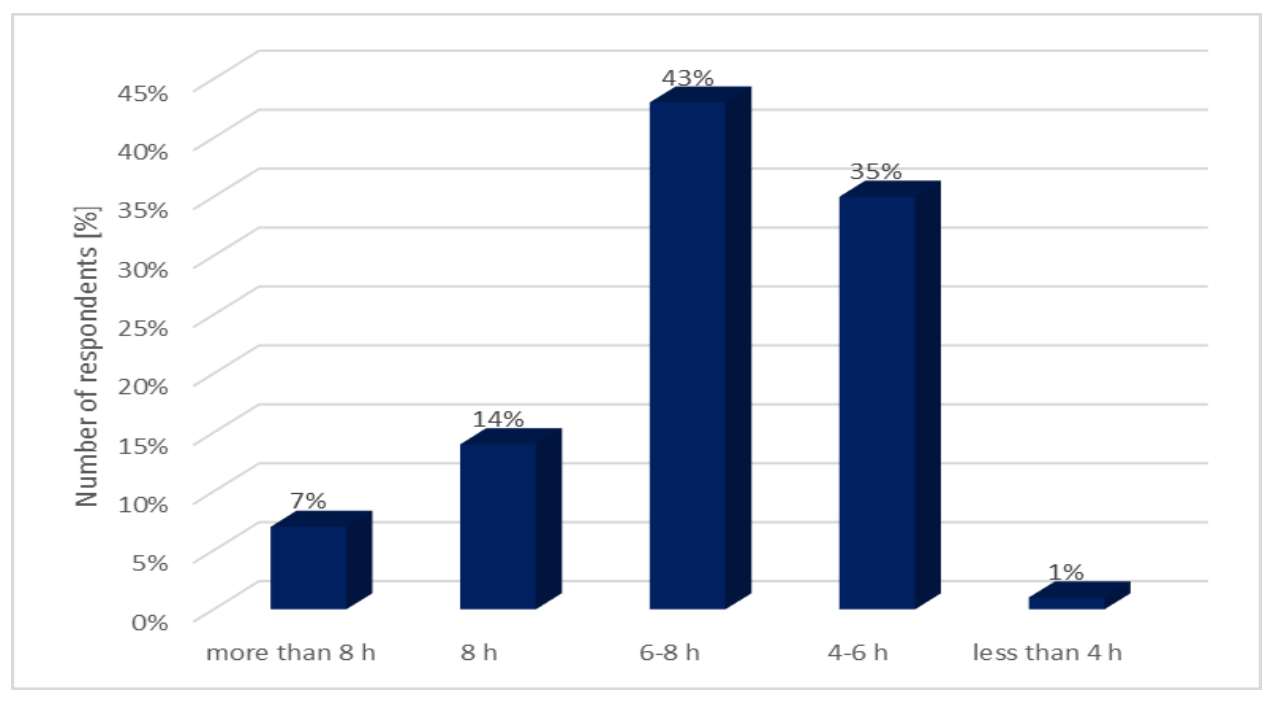

Figure 5. Number of hours spent sleeping (Source: Study of authors) 
Only $14 \%$ of respondents manage to sleep 8 hours a day, as generally recommended. The highest number of respondents (43\%) said 6-8 hours. The time intervals of 4-6 hours and less than 4 hours a day were chosen by $8 \%$ in both cases. An increasing amount of evidence indicates that sleep habits are crucial factors in the occurrence of occupational and traffic accidents (Garbarino, Nobili, Beelke, De Carli, \& Ferrillo, 2001; Akerstedt, Fredlund, Gillberg, \& Jansson, 2002; Pérez-Chada et al., 2005; Smolensky, Di Millia, Ohayon, \& Philip, 2011; Garbarino et al., 2017).

Another question aimed at the frequency of physical activity. The responses are shown in Figure 6.

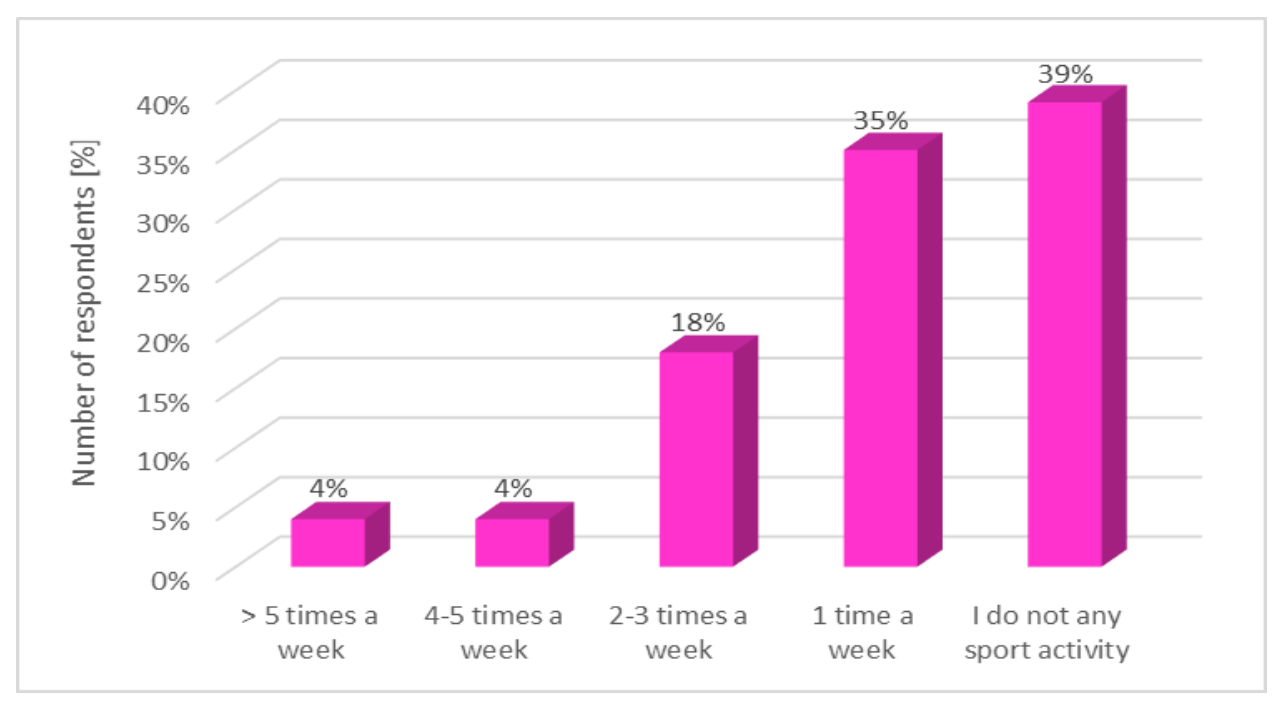

Figure 6. Frequency of physical activity during a day (Source: Study of authors)

Most respondents have reported that they do not do any physical activity (39\%), or they perform it only once a week $(35 \%)$. On the contrary, $8 \%$ of respondents perform physical activity more often (4\% - 4-5 times a week and $4 \%$ - more than 5 times a week). (Bergerová, 2018)

The last question was open, and respondents were asked to describe their physical activity, whether and what equipment they used, whether they practiced in a rest area or inside the cab, or possibly any other beneficial experience or comments on this topic. Their responses were as follows: walking, jogging, skipping rope, pressups, chin-ups, squats, sit-ups, dumbbells, Powerball (while driving); I have a huge cab where I can do press-ups and sit-ups during breaks; hiking in the close vicinity - short breaks every $5 \mathrm{~km}$, a 24-hour break every 16-29 km, sauna - if available; rubber ring squeezing; stretching, spine mobility exercises inside the cab or in the car park; "I used a horizontal bar in a trailer for chin-ups"; loading and unloading; jogging, ice hockey (player), floorball (goalkeeper); cycling; fitness centre; I help my parents with heavy manual work and daily manipulate the hand pallet truck, spine and neck stretching and mobilisation to prevent pain from long sitting; spinner; horse riding, housework and fitness centre occasionally; common light exercise in a car park; football, football-tennis; anything is possible; folding bicycle, in-line skating; various stretching exercises; anchoring the goods; home fitness; shovelling the loading area; swimming at home and climbing up and down the cab at work, taking the cover off the trailer, gate opening several times a day; trapeze on rubber bands; tennis; during the break, I manage only food and sleep, no time for sport; kettlebells; badminton; sit-ups in a cab and push-ups in a trailer; loading pallets on a deck; gardening; TRX, trapeze, P-bars or gym nearby; rubber band, squeezing ring; cross fit; yoga; plank; according to the weather, with my own body weight; diving; bed exercise, little space and great tiredness; strengthener for the forearm and wrist; manipulation with pallets, body building exercises in a trailer; work with courts, heavy chain, wooden beams, fast walk round the trailer - several times a day; exercises only at home, no time in a cab; no time; none. These responses correspond to the finding of Gilson et al. (2017), who claim that drivers have a range of barriers that limit their physical activity: perceived lack of time, fatigue and poor physical infrastructure. 


\section{Conclusion}

The questionnaire survey was attended by 270 respondents - truck drivers aged 18-70. It has been revealed that more than half of them $(51 \%)$ suffer from overweight or obesity. The body weight of $68 \%$ of respondents has increased after starting their job of professional drivers. Moreover, this job has other negative aspects as well, such as irregular eating regimen, insufficient sleep and lack of physical activity. Only $12 \%$ of respondents follow the principles of healthy eating to have 5 or more meals a day, and $44 \%$ of drivers eat only 1-2 meals daily. The recommended 8 hours of sleep are respected by only $14 \%$ of respondents, while $8 \%$ sleep less than 4 hours. Insufficient sleep is very dangerous and micro-sleep often leads to car accidents. Concerning physical activity, the highest number of respondents (39\%) do not perform any sport activity, their most common reasons being the lack of free time and opportunities for exercise and walk. This situation could be improved by better education for a healthy lifestyle and better support from management.

\section{References}

Akerstedt, T., Fredlund, P., Gillberg, M., \& Jansson, B. (2002). A prospective study of fatal occupational accidents - relationship to sleeping difficulties and occupational factors. Journal of Sleep Research, 11(1), 69-71. https://doi.org/10.1046/j.1365-2869.2002.00287.x

Albert, W. J., Everson, D., Rae, M., Callaghan, J. P., Groll, J., \& Kuruganti, U. (2014). Biomechanical and ergonomic assessment of urban transit operators. Work, 47(1), 33-44. https://doi.org/10.3233/WOR-131683

Angeles, R., McDonough, B., Howard, M., Dolovich, L., Marzanek-Lefebvre, F., Qian, H., \& Riva, J. J. (2014). Primary health care needs for a priority population: A survey of professional truck drivers. Work, 49(2), 175181. https://doi.org/10.3233/WOR-131649

Anstey, K. J., Wood, J., Lord, S., \& Walker, J. G. (2005). Cognitive, sensory and physical factors enabling driving safety in older adults. Clinical Psychology Review, 25(1), 45-65. https://doi.org/10.1016/j.cpr.2004.07.008

Apostolopoulos, Y., Sönmez, S., Shatell, M. M., Gonzales, C., \& Fehrenbacher, C. (2013). Health survey of U.S. long-haul truck drivers: Work environment, physical health, and healthcare access. Work, 46(1), 113-123. https://doi.org/10.3233/WOR-121553

Bergerová, S. (2018). Výživové zvyklosti a pohybová aktivita řidičů kamionové dopravy [Eating habits and physical activities in truck drivers] (Bachelor's thesis). Brno: Fakulta Sportovních Studií, Masarykovy Univerzity.

Crizzle, A. M., Bigelow, P., Adams, D., Gooderham, S., Myers, A. M., \& Thiffault, P. (2017). Health and wellness of long-haul truck and bus drivers: A systematic literature review and directions for future research. Journal of Transport \& Health, 7(Part A), 90-109. https://doi.org/10.1016/j.jth.2017.05.359

Fisher, D. L., Rizzo, M., Caird, J. K., \& Lee, J. D. (2011). Handbook of driving simulation for engineering, medicine, and psychology. Boca Raton: Taylor \& Francis Group.

Garbarino, S., Nobili, L., Beelke, M., De Carli, F., \& Ferrillo, F. (2001). The contributing role of sleepiness in highway vehicle accidents. Sleep, 24(2), 203-206. https://psycnet.apa.org/doi/10.1093/sleep/24.2.1a

Garbarino, S., Magnavita, N., Guglielmi, O., Maestri, M., Dini, G., Bersi, F. M., ... Durando, P. (2017). Insomnia is associated with road accidents. Further evidence from a study on truck drivers. PLoS ONE, 12(10): e0187256. https://doi.org/10.1371/journal.pone.0187256

Gilson, N. D., Pavey, T. G., Wright, O. R. L., Vendelanotte, C., Duncan, M. J., Gomersall, S., ... Brown, W. J. (2017). The impact of an $\mathrm{m}$-Health financial incentives program on the physical activity and diet of Australian truck drivers. BMC Public Health, 17(1): 467. https://doi.org/10.1186/s12889-017-4380-y

Hege, A., Apostolopoulos, Y., Perko, M., Sönmez, S., \& Strack, R. (2016). The work organization of long-haul truck drivers and the association with body mass index. Journal of Occupational and Environmental Medicine, 58(7), 712-717. https://doi.org/10.1097/JOM.0000000000000734

Jurnikl, J. (1986). Životni způsob řidičů mezinárodni kamionové dopravy (TIR) [Lifestyle of drivers for International Road Transport (IRT)] (Diploma thesis). Brno: Filozofická Fakulta Univerzity J. E. Purkyně v Brně.

Lemke, M., Hege, A., Perko, M., Sönmez, S., \& Apostolopoulos, Y. (2015). Work patterns, sleeping hours and excess weight in commercial drivers. Occupational Medicine, 65(9), 725-731. https://doi.org/10.1093/occmed/kqv080 
Marqueze, E. C., Ulhoa, M. A., \& Moreno, C. R. (2012). Irregular working times and metabolic disorders among truck drivers: A review. Work, 41(Suppl. 1), 3718-3725. https://doi.org/10.3233/WOR-2012-0085-3718

Miller, S. M., Taylor-Piliae, R. E., \& Insel, K. C. (2016). The association of physical activity, cognitive processes and automobile driving ability in older adults: A review of the literature. Geriatric Nursing, 37(4), 313-320. https://doi.org/10.1016/j.gerinurse.2016.05.004

Pérez-Chada, D., Videla, A. J., O’Flaherty, M. E., Palermo, P., Meoni, J., Sarchi, M. I., ... Durán-Cantolla, J. (2005). Sleep habits and accident risk among truck drivers: A cross-sectional study in Argentina. Sleep, 28(9), 1103-1108. https://doi.org/10.1093/sleep/28.9.1103

Poláček, B. (2017). Kapitoly z mezinárodního dopravního práva III [Chapters from International Transport Law]. Praha: Wolters Kluwer.

Puhkala, J., Kukkonen-Harjula, K., Aittasalo, M., Mansikkamäki, K., Partinen, M., Hublin, C., ... Fogelholm, M. (2015). Lifestyle counseling in overweight truck and bus drivers - Effects on dietary patterns and physical activity. Preventive Medicine Reports, 4, 435-440. https://doi.org/10.1016/j.pmedr.2016.08.012

Ronna, B. B., Thiese, M. S., Ott, U., Effiong, A., Murtaught, M., Kapellusch, J., \& Hegmann, K. (2016). The association between cardiovascular disease risk factors and motor vehicle crashes among professional truck drivers. Journal of Occupational and Environmental Medicine, 58(8), 828-832. https://doi.org/10.1097/JOM.0000000000000806

Rosso, G. L., Perotto, M., Feola, M., Bruno, G., \& Caramella, M. (2015). Investigating obesity among professional drivers: The high risk professional drivers study. American Journal of Industrial Medicine, 58(2), 212-219. https://doi.org/10.1002/ajim.22400

Sangaleti, C. T., Trincaus, M. R., Baratieri, T., Zarowy, K., Ladika, M. B., Menon, M. U., ... Consolim-Colombo, F. M. (2014). Prevalence of cardiovascular risk factors among truck drivers in the South of Brazil. BMC Public Health, 14: 1063. https://doi.org/10.1186/1471-2458-14-1063

Sieber, W. K., Robinson, C. F., Birdsey, J., Chen, G. X., Hitchcock, E. M., Lincoln, J. E., \& Sweeney, M. H. (2014). Obesity and other risk factors: The National Survey of U.S. long-haul truck driver health and injury. American Journal of Industrial Medicine, 57(6), 615-626. https://doi.org/10.1002/ajim.22293

Smolensky, M. H., Di Millia, L., Ohayon, M. M., \& Philip, P. (2011). Sleep disorders, medical condition, and road accident risk. Accident: Analysis and Prevention, 43(2), 533-548. https://doi.org/10.1016/j.aap.2009.12.004

Šucha, M., Černochová, D., Rehnová, V., Šrámková, L., \& Zámečník, P. (2015). Metody pro dopravněpsychologické vyšetření: Posuzování psychické způsobilosti $k$ ř́zení silničních motorových vozidel [Clinical examination methods for truck drivers: Assessment of psychological fitness for motor vehicle drivers]. Praha: Hogrefe.

Thiese, M. S., Moffitt, G., Hanowski, R. J., Kales, S. N., Porter, R. J., \& Hegmann, K. T. (2015b). Commercial driver medical examinations: Prevalence of obesity, comorbidities, and certification outcomes. Journal of Occupational and Environmental Medicine, 57(6), 659-665. https://doi.org/10.1097/JOM.0000000000000422

Thiese, M. S., Ott, U., Robbins, R., Effiong, A., Murtaugh, M., Lemke, M. R., \& Hegmann, K. t., (2015a). Factors associated with truck crashes in a large cross section of commercial motor vehicle drivers. Journal of Occupational and Environmental $\quad$ Medicine, $\quad$ 57(10), https://doi.org/10.1097/JOM.0000000000000503

Trick, L. M., Enns, J. T., Mills, J., \& Vavrik, J. (2004). Paying attention behind the wheel: A framework for studying the role of attention in driving. Theoretical Issues in Ergonomics Science, 5(5), 385-424. https://doi.org/10.1080/14639220412331298938

Zákon č. 361/2000 Sb. o provozu na pozemních komunikacích (Silniční zákon) [Act no. 361/2000 on Road Traffic] (2000). Praha: Ministerstvo Dopravy. Retrieved from https://www.cspsd.cz/125-zakon-c-361-2000-sb-osilnicnim-provozu 